\title{
The Crisis in Discourse: As an Event, a Discursive Semantics, and a Culture
}

\author{
Sandrine Reboul-Touré
}

Received: 28 June 2021 / Accepted: 28 June 2021 / Published online: 4 August 2021

(C) Springer-Verlag GmbH Deutschland, ein Teil von Springer Nature 2021

\begin{abstract}
La crise sanitaire « (`the health crisis $<$ ) that began in 2020 has had an impact on all levels of society, notably in the linguistic realm, where it has generated an abundance of discourse and lexical creations. The present article is based on a corpus from French print news corpus drawn from the databases Factiva and Europresse. The concept of »crisis«, a core notion in the underlying reflection, has brought in its wake many linguistic issues, including the gender of »covid-19«, the various different names for the so-called crisis (»pandemic «, »health crisis«, etc.), and the competition between »social distancing « and »physical distancing «. To begin, I use some of the many concepts available in the domain of discourse analysis to analyze the event itself and the naming process, and I make some proposals in the framework of discursive semantics. Next, I tackle the issue of lexical creativity while distinguishing two linguistic spheres, that of institutional discourse and that of the discourse of ordinary people. I study some of these neologisms by noting their spread throughout the current discourse and their inclusion in common French dictionaries. Lastly, I pave the way toward a contrastive discourse analysis that takes languages and cultures into account.
\end{abstract}

Keywords Discourse Analysis · Event $\cdot$ Naming $\cdot$ Neology $\cdot$ Lexicology $\cdot$ Crisis

Sandrine Reboul-Touré $(\bowtie)$

EA 7345 Clesthia, Language, Systems, Discourse, University Sorbonne Nouvelle, Paris, France

E-Mail: sandrine.reboul-toure@sorbonne-nouvelle.fr 


\section{Die Krise im Diskurs: Ereignis, Diskurssemantik, Kultur}

Zusammenfassung »La crise sanitaire « (>die Gesundheitskrise $<$ ), die im Jahr 2020 begann, hat sich auf alle Ebenen der Gesellschaft ausgewirkt, vor allem im sprachlichen Bereich, wo sie eine Fülle von Diskursen und Wortschöpfungen hervorgebracht hat. Dieser Artikel basiert auf einem französischen Zeitungskorpus, das aus den Datenbanken Factiva und Europresse stammt. Das Konzept der »Krise«, ein Kernbegriff der vorliegenden Überlegungen, hat viele sprachliche Probleme ins Blickfeld gebracht, darunter die Frage nach dem grammatischen Geschlecht von »covid-19«, die verschiedenen Bezeichnungen für die Krise (»Pandemie«, »Gesundheitskrise« usw.) und die Konkurrenz zwischen »sozialer Distanzierung « und »physischer Distanzierung «. Zu Beginn verwende ich einige der zahlreichen Konzepte, die im Bereich der Diskursanalyse verfügbar sind, um das Ereignis selbst und den Nominationsprozess zu analysieren, und ich mache einige Vorschläge im Rahmen der Diskurssemantik. Als nächstes befasse ich mich mit der Frage der lexikalischen Kreativität, wobei zwei sprachliche Sphären unterschieden werden, die des institutionellen Diskurses und die des Alltagsdiskurses. Ich untersuche einige der Neologismen anhand ihrer Verbreitung im aktuellen Diskurs und ihrer Aufnahme in gängige französische Wörterbücher. Schließlich erweitere ich die Überlegungen in Richtung einer kontrastiven Diskursanalyse, die Sprachen und Kulturen mit einbezieht.

Schlüsselwörter Diskursanalyse $\cdot$ Ereignis $\cdot$ Nomination $\cdot$ Neologie Lexikologie · Krise

There is still no single name for the crisis we are currently undergoing. In the end, will it be named on the basis of the date, as in la crise de 1929 (`the 1929 crisis $<$ ), la crise de 2008 (>the 2008 crisis<), and now la crise de 2020 (>the 2020 crisis<)? Or will it be named on the basis of its theme, as in la crise de la vache folle (>the mad cow crisis $<$ ), la crise des subprimes ( $>$ the subprime crisis $<$ ), la crise du covid19 (>the covid-19 crisis $<$ )? Or something else? ${ }^{1}$ The current crisis stands out by the fact that, due to its duration, it is affecting all individuals; this allows us to use it as an object of study at the very time it is taking place. Importantly, I will point out the characteristics specific to today's crisis, from the linguistic standpoint in particular. I begin by raising the question of how a given event is delineated and named: several names are competing here but the expression crise sanitaire (>health crisis $<$ ) seems to have risen to the top. Next, I will show how the current crisis is affecting the discursive and lexical levels, via an outburst of lexical creativity: new words have emerged in both the public and private spheres to find ways of expressing new realities. In the framework of a discourse analysis revolving around

\footnotetext{
1 Translator's note: Literal translations are proposed here. Some of the other terms actually used in English are: the Great Crash of 1929, The Wall Street Crash of 1929, The Great Depression, the 2008 Financial Crisis, the 2020 Health Crisis, the Outbreak of Mad Cow Disease, the Subprime Mortgage Crisis, and the Covid-19 Recession.
} 
words, this impact on the language sheds new light on linguistic concepts at the macro- and micro-structural levels.

In the first part of this paper, I present the concept of crise (>crisis<), and also various viewpoints surrounding the word. In the second part, I raise the question of how an event and its naming are interrelated. Lastly, I list a few neologisms and new words ${ }^{2}$ that provide evidence of the effervescence of lexical creations in French, which is important to emphasize. I thus analyze phenomena related to what can be called dire la crise (>talking about the crisis $<$ ) by seeing where discourse analysis and lexicology converge.

\section{Crise (crisis): A concept, a word, a vocable, and a lexeme}

\subsection{The concept}

The concept of crisis can be situated in a sociological and philosophical framework, or even in a transdisciplinary one. In the 1970s Edgar Morin brought out various aspects of this concept, which even led him later to speak of »a smoldering crisis of civilization $\ll$ (Morin 2020, p. 14; our translation):

The notion of crisis has been extended during the 20th century to touch upon all horizons of contemporary knowledge. There does not exist any domain nor problem which is not haunted by the idea of crisis: capitalism, society, the couple, the family, values, youth, science, law, civilization, humanity.

But this notion, by being generalized, has been somehow emptied from the inside. Originally, Krisis meant decision: in the evolution of an uncertain process, it was the decisive moment which allowed a diagnosis. Today crisis means lack of decision. It is the moment out of which springs uncertainties as well as disruption.

When the concept of crisis was limited to the economic sector, one could at least recognize it by some quantified characteristics: decreases (of production, consumption, etc.); increases (of unemployment, bankruptcies, etc.). But as soon as it was expanded to the cultural domain, to civilization, to humanity, the notion lost all boundaries. Using the term merely allows one to say that something is wrong. But that information is provided at the cost of general obscuring of the notion of crisis. (Morin 1976, p. 149)

Faced with the »emptiness « of this notion, Edgar Morin proposed a science of crises, which he called »crisology«.

\subsection{Different facets of crise as a word}

In another theoretical framework, that of the language sciences, Marie Veniard took an interest in the word crise and gathered data from a corpus of the daily French press (Le Monde and Le Figaro) during the conflict in France about freelance entertainment

\footnotetext{
2 See footnote 15 .
} 
work (2003-2004). ${ }^{3}$ She described how the word crise functions at different levels of discourse contextualization, which [...] led her to establish a »lexico-discursive profile $\ll$ of the word in a particular event:

The notion of a lexico-discursive profile is integrated into lexical discourse analysis as a lexical entry (Marcellesi 1976; Née/Veniard 2012; our translation). [...] [It] attempts to account for how lexical units are articulated with the discourse, whether it be a question of associative relationships between lexical elements or interactions between a lexical unit and the text and discourse levels. (Veniard 2013, p. 222; our translation)

In the analysis I propose, we see a convergence between word and discourse. Even though, in line with Edgar Morin, the notion of crisis loses all contours, a linguistic study of the word crise, in which it is specified by different co-texts, allows us to discern some more clearly identified aspects. The term word is far too vague to be relevant in linguistics; everyone knows what a word is, but it is nonetheless difficult to define. Saying the word »word « already means participating in the first step of metalinguistic reflection. »The word then enters into abstract systems of representation that necessitate the creation of new names to explore the different viewpoints at the heart of the language sciences « (Petiot/Reboul-Touré 2009, p. 16; our translation). That is why I decided to use the term lexeme to refer to a word that has been stabilized in the language - as reflected by its inclusion in French dictionaries - and the term vocable to refer to the various concrete realizations found in discourse. Note that other viewpoints are possible for analyzing crisis as a »word «, notably in the neological framework (see footnote 15).

For vocables, a vast, diversified corpus is supplied by the database Factiva, which compiles many news articles and graphs ${ }^{4}$, and the database Europresse ${ }^{5}$. Figure 1 plots the number of occurrences of the vocable crise and shows the yearly distri-

Fig. 1 Number of occurrences per year of crise ( $>$ crisis $<$ ) between 2005 and January 2021

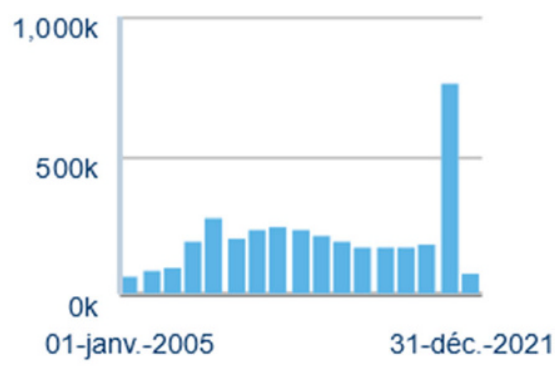

Distribution: annuel

\footnotetext{
3 Concerning this crisis, see France Info https://www.francetvinfo.fr/politique/intermittents/le-conflitdes-intermittents-du-spectacle-en-cinq-questions_617771.html [retrieved March 3, 2021].

4 Factiva is a database that provides access in several languages to newspapers, journals, magazines, news agencies, etc.

5 Diffusion of printed news on the internet. Europresse gives access to Libération and the newspaper Le Monde, neither of which is included in Factiva (restricted content for our academic accounts).
} 
bution between January 1, 2005 and January 31, 2021. ${ }^{6}$ Here, we can see a rise in occurrences in 2008-2009; this is the period of the financial crisis of 2008. There is also an exceptionally high jump in 2020 , the year with the greatest number of occurrences of crise seen in the press and news agencies:

Data can thus be gathered from many articles to analyze the different values taken on by the vocable crise, depending on the context in which it appears. A lexicometric analysis to explore large corpora would be relevant here, but I chose instead to do a qualitative analysis by reading many excerpts and making queries at various times during the year 2020. I noted a range of semantic features as a function of the cotexts in which the vocable occurred. On this basis, we can consider crise to be a vocable with various semantic facets that depend on the adjective (for example) that describes it. In French, it is the context on the right side of crise - in the framework of a lexical discourse analysis - that indicates its semantic features. To draw up an inventory of the right contexts of the vocable crise, I explored the Factiva database. This inventory is highly diversified, which, if viewed from an overarching angle, might make it into a fuzzy notion. But a micro-structural linguistic analysis allowed me, in every case, to specify some particular aspects of the vocable crise.

Below are a few contexts noted during the period between January 1, 2020 and December 31, 2020. Overall, we see many unspecified occurrences of la crise; references to past crises such as crise financière (>financial crisis $<$ ), crise financière de 2008 (>financial crisis of 2008<), and crise de 2008 (>crisis of 2008<), crise des Gilets jaunes ( $>$ Yellow Vest crisis $<$ ), or la crise des 'gilets jaunes' (`the 'yellow vest' crisis $<$ ); as well as qualifiers of crise marked by an adjective: crise bancaire ( $>$ bank crisis $<$ ), crise climatique (>climatic crisis $<$ ), crise démocratique (>democratic crisis $<$ ), crise écologique (>ecological crisis $<$ ), crise économique (>economic crisis $<$ ), crise institutionnelle (>institutional crisis $<$ ), crise migratoire ( $>$ migration crisis $<$ ), crise mondiale (>Worldwide crisis $<$ ), crise politique (>political crisis $<$ ), crise sanitaire (>health crisis $<$ ), crise sociale ( $>$ social crisis $<$ ), crise systémique ( $>$ systemic crisis $<$ ), and so on. When noun modifiers are used, they generate phrases indicating the source of the crisis by referring back to the virus or the disease: crise $d u$ coronavirus (>crisis of the coronavirus $<$ ), crise du Covid-19 (>crisis of the ${ }^{\text {masc }}$ Covid-19<), crise du Covid (>crisis of the ${ }^{\text {masc }}$ Covid $<$ ), crise de la Covid-19 (>crisis of the ${ }^{\text {fem }}$ Covid-19<), and crise COVID (〉COVID crisis $<)$.

Fig. 2 Number of occurrences per year of crise sanitaire ( $>$ health crisis $<$ ) between 2010 and January 2021

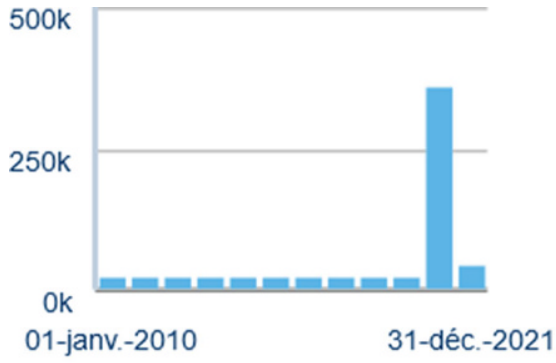

Distribution: annuel

\footnotetext{
6 The rightmost bar indicates few occurrences because the year 2021 is currently in progress.
} 
Due to this novel situation, the vocable crise has entered into new co-texts and the compound expression, crise sanitaire (>health crisis $<$ ), has become the term most commonly used in the discourse of the press. This is notable ${ }^{7}$, as we can see in Figure 2.

From this analysis of the occurrences of crise in discourse, three findings stand out. The first concerns the determiner, which has a deictic value, insofar as the crisis in question is a known crisis, namely, the one we are living through right now and that began in early 2020. The person who says »la crise« is in fact referring to the crisis he/she is currently experiencing, thereby giving the »la« a deictic value.

The second finding is the cohesion between crise and sanitaire. The adjunction of sanitaire (>health $<$ ) to crise has existed for several decades. Studies based on the Gallica ${ }^{8}$ database for the oldest occurrences of the entry crise sanitaire pointed to a 1929 article $^{9}$ by A. Augustin Rey, Vice-President of the Societé de Médecine Publique et de Génie Sanitaire, entitled »La Mortalité, la Morbidité et la Crise de l'Habitation Française« (>Mortality, Morbidity, and the Crisis of French Habitation $<)^{10}$ :

\section{Example 1}

We have come to a crisis that could threaten social peace. It has a number of aspects:

Crise sanitaire (>health crisis $<$ ) — Characterized by the absence of repairs to old dwellings throughout the territory, outside of rebuilt regions; contaminated housing units, dwellers with tuberculosis, cancer; overpopulation with a concentration of enormous urban populations in furnished lodging and hotel rooms, detrimental to cleanliness as well as to the dignity and future of the family; absence of potable water and evacuation of waste water. (Our translation)

In the above excerpt, the crisis is mainly described in terms of various healthrelated aspects, but it does not refer to an event; it describes a situation. The corpus compiled for the year 2020 points out very many uses of crise in the context of crise sanitaire: it is no longer a mere crisis that affects health (the meaning of the noun plus the meaning of the adjective). We see a new compound emerging, crise sanitaire (>health crisis $<$ ), one that is more of a lexical unit than a syntactic sequence. This is due to the frozen link between the two-element compound and what it generally refers to, with approximately 354,471 realizations ${ }^{11}$ during the year 2020 .

\footnotetext{
${ }^{7}$ As a matter of fact, the data plotted in this graph are atypical compared to certain previously published studies such as those dealing with the vocable bien-être (>well-being $`$ ) (Reboul-Touré 2016) and biodiversité (>biodiversity $<$ ), which have exponential graphs with more and more occurrences of the keyword with each new year. In other words, the spread of the expression is increasingly great but is regular.

${ }^{8}$ Gallica is the electronic library of the Bibliothèque nationale de France, https://gallica.bnf.fr/accueil/fr/ content/accueil-fr?mode=desktop [retrieved March 3, 2021].

9 This article was drawn from a talk given at the April 24, 1929 session of the Societé de Médecine Publique and published in Le mouvement sanitaire (The Health Movement), the official organ of the Syndicat de médecins hygiénistes français and of the Societé de médecine publique, https://gallica.bnf.fr/ark:/ 12148/bpt6k122756c/f4.item.r=\%22crise\%20sanitaire\%22 [retrieved March 3, 2021].

10 The capital letters shown here are in the French text.

11 Factiva database.
} 
The third finding is prospective. It concerns the ramifications of the health crisis, which is central here in comparison to other crises (economic, political, social, etc.), in such a way that the crisis we are analyzing will, beyond its denotation, carry with it elements linked to »discursive memory«, a notion proposed by Jean-Jacques Courtine:

What we mean by the term »discursive memory « is distinct from psychological storage in memory [...]. The notion of discursive memory pertains to the historical existence of the utterance within discursive practices dictated by ideological devices [...]. (Courtine 1981, pp. 52-53; our translation)

This notion is »revisited « by Sophie Moirand:

As the analyzed events were unfolding, we encountered words and formulations — inscribed in the discursive materiality — that play a memory-triggering role without really allowing us to speak of »reported discourse $\ll$, or that seem to refer to representations drawn from domains of short- or long-term memory (Moirand 2007, §16; our translation)

So when we talk about the crise sanitaire in the future, it will likely be in reference to the 2020 crisis as the most striking one. Crise sanitaire will be linked to a state of emergency in health set out in the written legislation ${ }^{12}$, to the initial and firstever »confinement « period, to a later »reconfinement«, and to curfews. And it will carry with it a discursive memory associated with all of the above. At the present time, common French dictionaries like the Petit Larousse and the Petit Robert de a langue française mention various crises. In the Petit Robert 2020, for example, we find crise économique (>economic crisis $<$ ), crise politique (>political crisis $<$ ), crise $d u$ pouvoir (>power crisis $<$ ), crise ministérielle (>ministerial crisis $<$ ), crise diplomatique (>diplomatic crisis $<$ ), crise internationale (>international crisis $<$ ), crise du logement ( $>$ lodging crisis $<$ ), crise sociale ( $>$ social crisis $<$ ), but not crise sanitaire ( $>$ health crisis $<$ ). It is likely that, in future editions, these dictionaries will update the definition of crise by adding crise sanitaire to refer to all of the covid events that occurred in the year 2020.

\section{The event and its naming}

\subsection{The existential event and the event as an object: When a crisis becomes an event}

»An event undeniably constitutes an object of knowledge, an object of research in the human and social sciences, a locus of reflection for thinkers coming from all horizons « (Londei/Moirand/Reboul-Touré/Reggiani 2013, p. 11; our translation).

$12 »$ Art. L. 3131-13. The health-emergency state was declared by decree during the Council of Ministers and taken from the report of the Minister in Charge of Health.« [...], Emergency Decree No. 2020-290 of March 23, 2020, to handle the covid-19 epidemic. 
And among the salient linguistic questions regarding the crisis that began in 2020, one is the question of what to call what is happening, how to name the event:

When an event is »captured via communication«, as [Louis] Quéré said, one cannot help but wonder about the different ways of expressing the event, from when it is first put into words and images, described, and told; until later when it is designated at a particular moment (what is currently happening); until it takes shape within a complex system of discursive construction and temporality. (Londei/Moirand/Reboul-Touré/Reggiani 2013, pp. 11-12; our translation)

An event can be seen from several angles. It can be regarded as what is happening, in which case it becomes »thought of «. And, on another stratum, it is also something that is put into discourse. This is the angle that may get more or less amplified according to how much interest certain communities grant to it. Note that insignificant events can sometimes take on mediatic magnitude while real events that are important (for whom?) may slip by in silence:

The main distinction we can make is between events as contingent changes that happen concretely in our environment (existential events), and events as objects (objects of consciousness, of thought, of discourse, of inquiry, of judgment). The major difference between the two forms is the degree of symbolization. [...] These two forms of an event coexist in our experience, and as beings capable of judging, we are constantly in the process of converting existential events into objects, essentially for practical purposes, that is to say, so as to be able to intervene in the course of events, ease their blow, harness them a little. (Quéré 2013, pp. 5-6; our translation)

It is within this dynamic that a crucial connection between an event and its naming appears. »The decision to dwell upon the act of event naming reveals certain aspects of the naming process. Long studied for common nouns and proper nouns, this process can also be studied for the names of events, which share properties with both of these categories « (Moirand/Reboul-Touré 2015, p. 107; our translation).

Recall that naming is »the act by which a subject names in discourse, i.e., categorizes a referent by inserting it in a class of objects identified in the lexicon, unless he/she wants to innovate via a neologism « (Détrie/Siblot/Vérine 2001, p. 205; our translation). According to these authors, the performative dimension of this original act of naming thus becomes manifest, and semanticists speak of the act of christening.

Indeed, when something actually happens, it is likely to trigger spoken exchanges, which in turn can be taken up by the press, thereby contributing to its spread. In the face of new realities, neologisms will be coined (see Section 3).

\subsection{Naming an event: On subjectivity in language ${ }^{13}$}

Naming can thus be regarded as a process that produces a result: the name that will be repeatedly given to a referent and the word that will occasionally be used

13 Here, I am reusing the title of an article by Emile Benveniste [1958], 1966. 
to refer to it in discourse. If journalists often used the vocable crise in their articles in 2020, it is interesting to see what crisis they were talking about. An analysis of journalistic co-texts points out that the crisis in question referred to a wide variety of referents during the first two months of the year: crise écologique (>ecological crisis $<$ ), crise du politique (>crisis of politics $<$ ), crise du libéralisme (>crisis of liberalism $<$ ), crise sociale ( $>$ social crisis $<$ ), crise de réputation (>reputation crisis $<$ ), crise des migrants (>migrant crisis $<$ ), crise du secteur bancaire (>banking sector crisis $<$ ), crise des retraites ( $>$ retirement crisis $<$ ), crise de la société (>crisis of society<), crise de confiance ( $>$ confidence crisis $<$ ), crise climatique ( $>$ climate crisis $<$ ), etc. Some examples are given below.

Example 2

Landing right in the midst of the retirement crisis, the catastrophic delinquency statistics elicited few political reactions, but they contributed to the crisis of society and the crisis of confidence in public action. (Le Figaro, February 4, 2020; our translation)

\section{Example 3}

For those of our generation who, overwhelmed by scientific proofs, are aware of the monstrosity of the changes currently taking place and are finding themselves faced with a general lack of action, as if condemned to remain spectators, it is difficult to understand such a difference in treatment between mobilization against the retirement reform and a climate crisis that stays in the background of your movements, even though it jeopardizes the very existence of such a system. (Le Monde, February 13, 2020; our translation).

Then in mid-February 2020, when the news started to be about the development of a disease due to a coronavirus in Wuhan, China, the vocable crise began to focus on that particular event, an existential event that would become an object, with a highly productive body of discourse and a leap in the number of occurrences of crise, as we can see in Figure 3.

Mediatic agitation was to accompany this novel event. We can see two discursive events. The first occurred in mid-February 2020 when journalists began attempting to find a name for the new crisis taking shape. The second is the fact that the use of crise was to be mainly associated with the coronavirus crisis. Hesitations about how to name the phenomenon are clearly present. I found various possible names, in particular, uses of épidémie (>epidemic <) ${ }^{14}$, as seen in the examples below.

\section{Example 4}

The epidemic of coronavirus COVID-19 currently underway, which began in Wuhan at the end of last year, clearly illustrates the threat posed by emergent infectious diseases, not only for human and animal health, but also for social stability, commerce, and the global economy. Now, many indicators lead us to

\footnotetext{
14 Epidémie (`epidemic $<$ ): »Accidental outbreak of a large number of cases (of a transmissible infectious disease), or a substantial increase in the number of cases in a given region or within a given community." (Le Petit Robert de la langue française 2020; our translation).
} 
Fig. 3 Number of occurrences of crise ( $>$ crisis $<$ ) per month throughout the year 2020

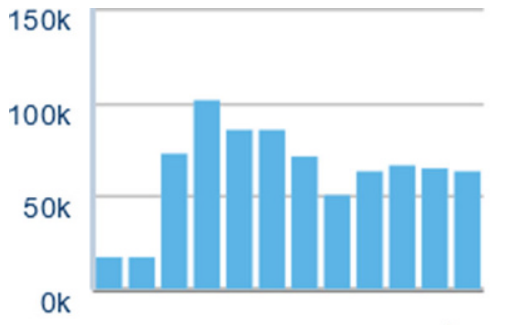

01-janv.-2020 31-déc.-2020

Distribution: Mensuel

believe that the frequency of emergence of new infectious agents could increase in the upcoming decades, causing dread of an imminent worldwide epidemiological crisis. Indeed, human activities entail profound alterations in the use of land and substantial disruption of biodiversity, in many places on our planet. (La Tribune, February 14, 2020; our translation)

\section{Example 5}

The first public meeting in France about the epidemic crisis, which surprised the entire world in mid-January, was held yesterday evening in Bordeaux, under the initiative of the University Hospital and the »Sud Ouest « [a regional daily]. (Sud Ouest, February 26, 2020; our translation)

Then came a turning point, when the head of the World Health Organization ${ }^{15}$ made the following declaration on March 11, 202016:

Example 6

In the past two weeks, the number of cases of COVID-19 outside China has increased 13-fold, and the number of affected countries has tripled. [...]

We have therefore made the assessment that COVID-19 can be characterized as a pandemic.

Pandemic is not a word to use lightly or carelessly. It is a word that, if misused, can cause unreasonable fear, or unjustified acceptance that the fight is over, leading to unnecessary suffering and death.

[...] We have never before seen a pandemic sparked by a coronavirus. This is the first pandemic caused by a coronavirus.

This is interesting, since in this case, the act of naming is identifiable; it is an act of christening and only the WHO can make the decision. The print media had anticipated the arrival of the $»$ word $«$, and from there, it would spread and resound, as in the following examples.

\footnotetext{
15 Doctor Tedros Adhanom Ghebreyesus.

$16 \mathrm{https} / / / \mathrm{www}$. who.int/fr/director-general/speeches/detail/who-director-general-s-opening-remarks-atthe-media-briefing-on-covid-19---11-march-2020 [retrieved March 3, 2021].
} 


\section{Example 7}

The WHO still refuses to use the word »pandémie« (>pandemic $<$ ), but this oratory caution seems to be increasingly uncalled for when there are clusters with hundreds and hundreds of cases in several countries. Above a few dozen diseased individuals in a given country, being able to totally block the virus is indeed illusory, and the only viable strategy becomes simply trying to limit its progression. (Le Figaro, February 28, 2020; our translation)

\section{Example 8}

While the virus impacts elections, as has often been said (fewer meetings and less handshaking, predictable rise in abstentions), do elections impact the handling of the crisis? A »French exception« is emerging. The virus is spreading (rapidly), health professionals are worried (not all of them), Italy shutters, the WHO declares the »pandémie « (>pandemic $<$ ) and warns about paltry management, but - don't tell anyone - France is voting. (Les Echos, March 12, 2020; our translation)

Thus, in accordance with the name chosen, journalists make their point of view known and seek to alert the reader in various ways. This is where it is possible to extend the examples used by Emile Benveniste. Indeed, in his article on subjectivity in language, he links subjectivity to the subject who has taken the floor:

It is in and through language that man constitutes himself as a subject, because language alone establishes the concept of »ego « in reality, in its reality which is that of the being. The »subjectivity « we are discussing here is the capacity of the speaker to posit himself as »subject«. (Benveniste 1966, p. 259; for the English version see Benveniste 1971)

His next step was to extract grammatical elements such as certain pronouns, verb tenses, etc. (which can be called subjectivity markers), including elements that have since fallen under the heading »pragmatics «, like je jure (>I swear<). It seems possible to extend this by considering that the choice of such and such a way of »talking about the crisis « is in fact indicative of the speaker's viewpoint: using pandemic is more anxiety-generating than using crisis.

From then on, it was the vocables crise and more often crise sanitaire that would be employed regularly (see Section 1), as in:

\section{Example 9}

Philippe Bourdeau, professor at Grenoble-Alpes University's Institute of Alpine Geography, noted a historical slap in the face, a sudden reversal: the major resorts, which until then were proud of their international clientele and their sturdiness, run the risk of being weakened the most by this crisis. (Libération, November 28, 2020; our translation)

\section{Example 10}

What the CSA [Superior Audiovisual Counsel] found is no less severe. The health crisis has »aggravated « an anomaly that public authority has been com- 
batting for many years: women, not as well represented in audiovisual media as men (41\% vs $59 \%$ ), often remain confined to the traditional female register: testimonials about their everyday life ( $55 \%$ vs $45 \%$ ). So during the health crisis, they were asked to talk, in the first person singular, about their experience of being a »confined mom « or a »victim of violence«, but they much less often donned the respected garb of an expert. (Le Monde, July 11, 2020; our translation)

The meaning of crise in the context of the year 2020 refers back to a more or less stable referent linked to the coronavirus. Concerning the compound crise sanitaire, it becomes the expression most commonly used; it undergoes a high degree of freezing, and due to its discursive realizations and its linguistic impact, it is the most significant health crisis. Accordingly, we have:

We chose to observe the construction of meaning in discourse by starting from elements that once were deemed to belong to external linguistics, but which are part of a linguistics that »would no longer fear reality (Siblot 1990, 1997; our translation). The study of the process of event naming indeed prompts us to extend some boundaries: that of proper nouns vs common nouns, and that of »internal« vs »external« linguistics, by relying on syntactical-semantic forms of co-texts. (Moirand/Reboul-Touré 2015, p. 108; our translation)

I have just presented some elements in the framework of lexical semantics. Now let us take a look at lexical creativity.

\section{Lexical creativity: From politics to people}

The current crisis has slipped into numerous realms of society and has prompted analyses in all domains of both the human sciences and the exact sciences. Researchers are called upon to make observations and analyses, and to stand back, in order to better understand the crisis and get beyond it. This approach, as standard as it seems, is in fact quite particular, notably at the linguistic level. The creation of new words ${ }^{17}$ was so great that journalists, wondering about how to go about their writing, tended to lean toward a metalinguistic stance (e.g., What gender should be chosen

\footnotetext{
17 In this part, I use the word »word « because the theoretical framework will be neology, which allows us to speak of »neologism « whenever words emerge in discourse but have not yet been entered into dictionaries, and to employ »new word « for words that have been entered into a dictionary and have thus lost their specificity.

$18 \gg$ Doit-on dire $>$ le< or >la< covid-19?« (>Should one say 'le' or 'la' covid-19?<), Pierre Ropert, France Culture, April 8, 2020, https://www.franceculture.fr/sciences-du-langage/doit-dire-le-ou-la-covid-19 [retrieved 3 March 2021].

19 »Pourquoi >confinement<, >quarantaine< ou >présentiel<? Les mots du coronavirus à la loupe« (>Why 'confinement', 'quarantine' or 'in-presence'? The words of coronavirus under a magnifying glass $<$ ), PierreLouis Caron, France Info, October 14, 2020, https://www.francetvinfo.fr/sante/maladie/coronavirus/ confinement/video-pourquoi-confinement-quarantaine-ou-presentiel-les-mots-du-coronavirus-a-la-loupe 4138871.html.
} 
for Covid-19? ${ }^{18}$ Which is better, semaine (>week $<$ ) or septaine ( $>$ seven days $<$ )? ${ }^{19}$ ). In order to find answers to these language uncertainties, journalists called upon linguists, treating them as experts. For my analysis here, one approach would be to take neology as my framework and give highly detailed descriptions of the new forms (Sablayrolles 2019). Instead, I chose a lexicological approach, which interrelates morphology and semantics.

\subsection{Grammatical gender variation}

The first linguistic question that came up revolves around the dual emergence of $l e$ covid-19 and la covid-19 - that is, use of the feminine (la) or masculine (le) definite article - with the most common wording of this question being, »Should one say le or la covid-19? «. This wording has a prescriptive tint and requires making a choice, with the underlying idea being that one of these uses is correct and the other is incorrect. I would like to develop another point of view, based more on variation and thus on the possible usage of both the feminine and the masculine genders. In the first uses of covid-19 in the news, the masculine prevailed:

Example 11

After 2019, a year full of huge court cases - France Telecom, Mediator, Abdelkader Merah, Bernard Tapie, Cardinal Barbarin, Balkany spouses, to mention only a few - the year 2020 looked like it was going to be just as intense ... even before le Covid-19 arrived and put in its two cents' worth. (Le Figaro, December 30, 2019; our translation)

Covid-19 is a creation in English, and when the word was brought into French, the question of gender was posed. Two points of view seem to have arisen. The first made the connection between coronavirus and covid-19, and given that in French we say »le coronavirus« and »le virus« (>the $\mathrm{e}^{\text {masc }}<$ ), le covid-19 was proposed by analogy. The second relies on the morphology of the word in English to identify cofor corona, $v i$ - for virus, and $d$ - for disease, and given that disease translates into French as la maladie, the compound construction retains the feminine gender of the noun maladie, hence la covid-19.

At the onset of the crisis, the masculine was used more often in the news, after which a few cases of the feminine appeared. To choose which gender to use, certain journalists relied on a decision made by the Académie française on May 7, 2020, under the rubric $»$ Dire, ne pas dire $«(>\text { What to say and not to say }<)^{20}$ :

Covid is the acronym of corona virus disease, and abbreviations and acronyms carry the gender of the noun that constitutes the head of which they are the abbreviation. [...] Corona virus disease means »disease caused by the corona virus ( $>$ virus in the form of a crown $<$ ) «. So, we should say la covid 19 (>the $\mathrm{fem}^{\mathrm{fe}}$ ) since the head noun is equivalent to the French feminine noun maladie ( $>$ disease $<$ ).

\footnotetext{
20 http://www.academie-francaise.fr/le-covid-19-ou-la-covid-19 [retrieved March 3, 2021; our translation].
} 
But insofar as the use of the masculine was already very widespread, the 2021 edition of the dictionary Petit Robert, chose to accept two variants: »Covid [...]: masculine or feminine noun «. With this variation-based decision, there is no longer an incorrect usage since both genders are accepted. My linguistic analysis can therefore take place at the discursive level. It would be interesting to see what spheres of language activity (Moirand/Reboul-Touré/Pordeus 2016; Reboul-Touré 2020) employ which gender. In France, the first occurrences of the feminine, la covid-19, in February 2020 came from certain journalists at France Culture and in specialized journals, but also in a few newspapers, as we can see in the examples below.

\section{Example 12}

138 health institutions were appointed in the struggle against the coronavirus. These are places where a parallel setup is organized so that persons with the $\mathrm{f}^{\mathrm{fem}}$ Covid-19 do not come into contact with any other patient. The setup is ready; we had learned how to put it in place during previous health crises. (Sciences et Avenir, February 29, 2020; our translation)

\section{Example 13}

Tuesday and Wednesday, the WHO organizes a forum on research and innovation in view of taking stock of the many still-existing unknowns of the $\mathrm{e}^{\mathrm{fem}}$ Covid-19 and of implementing a strategy to accelerate the research and development of treatments and vaccines against the novel coronavirus. (Le Monde, February 13, 2020; our translation)

Moreover, we are also hearing doctors interviewed on the radio or television using the feminine gender. ${ }^{21}$

It is worth noting that when there is a choice, the chosen solutions are not unanimous and cannot always be classified in terms of the injunctions »one must say « versus »one must not say « often made by the Académie française. The approach of a linguist is descriptive. Accordingly, I analyze concrete realizations produced by speakers. Sometimes, several solutions are possible and each conveys a choice that reveals a linguistic positioning based on the language-activity sphere, or even an individual positioning. From the terminological standpoint, a fundamental distinction is made between the virus itself — which has its own name, SARS-CoV-2 - and the disease called covid-19. Yet in French usage, we can see a metonymic sliding between the disease and the virus, in such a way that covid-19 can refer to both the disease and the virus.

\subsection{Lexical creations in institutional discourse}

In the institutional discourse, the lexical creations resulted from traditional morphological and semantic devices like derivation, compounding, and semantic neology.

${ }^{21}$ Queries of the Europresse database extracted 423,501 occurrences of le covid and 658,425 occurrences of la covid (between March 4, 2020, and March 4, 2021). 
When the word confinement ${ }^{22}$ (in connection with the current health crisis) appeared in the media, ${ }^{23}$ it first referred to restrictions imposed in Wuhan. Then later, it referred to measures taken to send expatriates home from China, which required a two-week-long quarantine in a closed residence in Carry-the-Rouet (La Provence, February 15, 2020). After that, the referent was modified when the AFP (AgenceFrance Presse, the French news agency), among others, foresaw a nationwide confinement in France:

Example 14

Several mass marketing chains in France informed the AFP that their stores were flooded with customers wanting to stock up on essential goods such as pasta, rice, or hygiene and cleaning supplies, to compensate for a potential confinement period due to the novel coronavirus. (Agence France Presse, March 2, 2020; our translation)

This potential confinement period did occur in the end, and was decreed in France to start on March 17 at noon:

\section{Example 15}

Last night, the Head of State announced some drastic new measures to curb the exponential propagation of the virus, including the confinement of the population for fifteen days at least, and the postponement of the second round of municipal elections (L'Humanité, March 17, 2020; our translation).

The progression of the uses of confinement in the printed news clearly reflects health constraints, with a peak in April (the first confinement period ran from March 17 to May 11, 2020) and a second peak in November (dates of the second confinement period: October 30 to December 15, 2020), as we can see in Figure 4.

At the end of the first confinement, the word déconfinement (>deconfinement<) was created; and at the onset of the second confinement the word reconfinement (>reconfinement $<$ ) appeared:

\section{Example 16}

Again yesterday during his televised speech announcing a gradual deconfinement period starting next May 11, the President of the Republic increased the pressure on insurance companies and stressed that he »would pay attention« to that sector's participation during the current period. (La Tribune, April 15, 2020; our translation)

\section{Example 17}

»There is still time to act«, warns Olivier Veran, who is in fact relying on this battery of decisions to flatten the curves. Although the government rebuffs at all costs the prospect of a reconfinement, even local, it is calling for »limiting social interactions «. (Le Berry Republicain, September 24, 2020; our translation)

22 For a study on historical semantics, see Thiéry-Riboulot 2020.

23 It was already being used for other referents (e.g., confinement following a fire in a warehouse). 
Fig. 4 Number of occurrences of confinement between January 1 st and December 31st, 2020

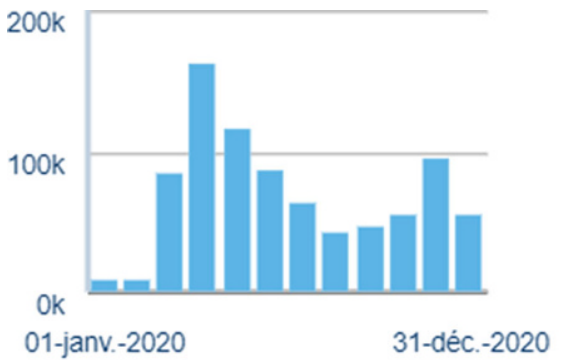

Distribution: Mensuel

We thus have a derivational paradigm (confinement, déconfinement, reconfinement) that abides perfectly by the morphological rules of French: the root, the prefix $d e^{-}$, and the prefix re-, which are highly productive. In the media, we also find the verbs confiner (>to confine $<$ ), déconfiner (>to deconfine $<$ ), and reconfiner (>to reconfine $<$ ), and less frequently, the nouns confiné (>the confined $<$ ), déconfiné (>the deconfined $<$ ), and reconfiné (>the reconfined $<$ ), and the adjectives confiné (>confined $<$ ), deconfiné (>deconfined $<$ ), and reconfiné (>reconfined $<$ ). Some of these neologisms have been added to dictionaries like the Petit Robert and have thus acquired the status of $»$ new word «, with the following definitions ${ }^{24}$ (Figure 5):

These dictionary entries allow us to consider these words as lexemes that have become part of the language. The lexicographic entry for confinement was updated by adding »the act of staying home to slow down the spread of an epidemic. Mesures de confinement (confinement measures) «, accompanied by its antonym déconfinement.

We see another derivational paradigm revolving around words ending in -aine (a French suffix meaning >group of $<$ ), with a base that is a number. Here, quarantaine (>quarantine $<$ ) is the typical example, but insofar as quarantaine means isolation for at least forty days, policymakers have coined some neologisms based on new $\gg$ realities «: septaine (>group of seven $<$ ), quatorzaine ( $>$ group of $14<$ ), as in the following example.

\section{Example 18}

The Scientific Council is in favor of reducing the fourteen-day isolation period to seven days. Quatorzaine becomes septaine. The word is formed from the

Fig. 5 Excerpt taken from the press kit »Le Robert présente ses mots nouveaux 2021《(Le Robert presents its new words)
DÉCONFINEMENT [dekõfinmã] nom masculin I ÉTYM. 1968 ;

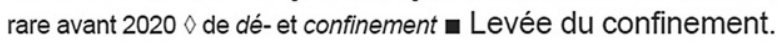
a CONTRAIRE : Confinement.

DÉCONFINER [dekőfine] verbe transitif (conjugaison 1) I ÉTYM. 1987 ; rare avant $2020 \diamond$ de dé- et confiner Mettre fin au confinement de (qqn.). a PRONOM. Région qui se déconfine. a CONTRAIRE : Confiner.

\footnotetext{
24 These words were inserted in electronic dictionaries only: the digitized version of Le Petit Robert and Dico en ligne Le Robert (Le Robert online dictionary), https://dictionaire.lerobert.com/ [retrieved March 3, 2021].
} 
word quarantaine and refers to a period of seven days. Had the isolation been for nine days, we would have said neuvaine (a group of nine days). So far, the septaine (pronounced as if it were spelled »setaine « like the number sept, pronounced »set«) referred to seven similar things. This usage of septaine has died out. For the period of seven days we haven't finished talking about, will it be pronounced »septaine« or »setaine«? That's just another unknown in this epidemic. The Belgians and the Swiss have remained faithful to pronouncing the $p$ : for the number 70, they haven't succumbed to using soixante-dix (>sixty-ten<) and continue saying septante (>seven-ty<). (Le Figaro, September 10, 2020; our translation).

The neologisms septaine and quatorzaine in connection with the current health crisis do not yet seem to be included in the common French dictionaries. Will they be so in the future?

Lastly, another series emerged with the words presentiel (>in-presence<, >in-person $<$, or $>$ face-to-face $<$ ) and distanciel ( $>$ at a distance $<$ ), raising many questions about orthographic dissimilarity. Le Dico en ligne le Robert chose to include presentiel, as in enseignement presentiel (>in-person instruction $<$ ), but not distanciel. These words already existed in the teaching world but they have been »democratized «. I would like to add demerdentiel (from se démerder, >to fend for oneself $<$ ) to this series; this word has mainly been seen on social media, but it also showed up in the Libération newspaper on September 16, 2020, in the following headline: »Universities: une rentrée en demerdential « (roughly, Universities: Coping on your own with the new school year) to refer to having to juggle in-person and remote instruction, depending on the circumstances.

In parallel with derivatives, compound words also appeared. I selected some compound words formed without hyphens, namely, patient zéro (>patient zero<), distanciation sociale (>social distancing $<$ ) versus distanciation physique (>physical distancing $<$ ), geste barrière (literally, >barrier gestures $<$, referring here to preventive health measures), and immunité collective (>herd immunity< or >collective immunity<). Compared to derivatives like confinement, déconfinement, and reconfinement, which can be readily understood because they are regular in the linguistic system, compounds have a linguistic utility on two levels: the discursive level, where we see a metalinguistic device used by journalists, and the lexicographic level, where we find an immediate entry in a commonly used dictionary like the Petit Robert. When these neologisms showed up in the printed news, they did so in definitional contexts, where journalists must specify their meaning, as in the following example.

\section{Example 19}

Just like history, science likes starting points, i.e., understanding a phenomenon by studying its origin. For the virus, we speak of patient zéro (>patient zero<), also called »cas index« (>index case <), the first human thought to have contracted a newly-mutated virus or brought it into a new zone before spreading it, without even knowing he was infected. The search for this unknown very often crystalizes passions. (Aujourd'hui en France, May 9, 2020; our translation) 
In the above excerpt, the competition between patient zéro/cas index, the verb to call, and the definitional elements in »first human thought to have contracted a newly-mutated virus « contribute to our metalinguistic reflection. ${ }^{25}$ Another competition, that between distanciation sociale (>social distancing $<$ ) and distanciation physique (>physical distancing $<$ ) led to discussions about neologisms and to articles entirely devoted to this linguistic debate. Some examples of article titles are:

» >Distanciation physique $<$ ou >distanciation sociale <: quelle formule adopter?« (> 'Physical distancing' or 'social distancing', which formulation to choose?<) (Le Figaro, April 29, 2020).

$»$ Pourquoi l'expression >distanciation physique < a remplacé celle de >distanciation sociale « (>Why the expression 'physical distancing' has replaced that of 'social distancing'<) (L'Obs, May 28, 2020).

» Distanciation sociale< et >distanciation physique «« ( 'Social distancing' and 'physical distancing' () (La Croix, May 27, 2020).

To explain the abandonment of distanciation sociale to the benefit of distanciation physique, some journalists requested the expertise of linguists, as in the example below:

\section{Example 20}

»The expression distanciation sociale is out of place. In English, social has retained its etymological sense. In French starting in 1830, it took on a political meaning, « explains the linguist Bernard Cerquiglini. We speak of »social questions «, »social issues «, and »social movements «. The word [...] is also found in the first article of the Constitution: »France is an indivisible, secular, democratic and social Republic«. As such, the term »physique« is more accurate because it refers to the body of an individual, whereas the social body qualifies society. Speaking of »distanciation physique « is putting the individual, in its flesh, at the heart of the discourse. Nothing prevents us from staying connected to others, a social connection, all the while remaining physically distant. (Le Figaro, April 29, 2020; our translation)

Distanciation sociale thus seemed inadequate, in addition to the fact that the compound is politically connoted, hence the creation of the neologism: distanciation physique. These two compounds have been added to the distanciation entry in the Petit Robert. Regarding immunité collective (>herd immunity<), it has been added to the definition of immunité, as follows: »Collective immunity, group immunity: immunity acquired by a sufficiently large proportion of the population to break the transmission chain of a contagious disease «. Note that patient zéro is defined in the zéro entry, as follows: »MED. Patient zero: the first person to have been contaminated by a pathogenic microorganism at the origin of an epidemic. Identifying patient zero.« The compound geste barrière (>preventive measure $<$ ) was added to the barrière entry, as follows »Barrier gesture or measure: precaution taken in everyday life to limit the propagation of a virus or a disease. Respect barrier gestures (abide by preventive measures) $\ll$.

\footnotetext{
25 See also the introduction to Section 3 and Examples 6, 7, and 18.
} 
The compounds selected here demonstrate an extremely rapid shift — one perhaps as yet never seen - from the status of neologism to that of new word. ${ }^{26}$

Finally, among the words I studied, some are preexisting words that acquired a new meaning, bringing us into the realm of semantic neology. An écouvillon ( $>$ swab $<$ ), which until then was a sort of broom or brush for cleaning, became »a little stick with a small brush or some absorbant matter, used to clean natural cavities or get samples« (Petit Robert). Another case in point is the word réserviste (>reservist<), which no longer means a member of the army reserves but a healthcare worker who is part of the health reserves.

Many other neologisms came to be, and with the arrival of vaccines, we are hearing »vaccinodrome « (>vaccine drome $<$ ) to refer to a mass vaccination site. Cleary, creativity lexical is still in full force. The most notable thing is that all of these words are constructed from elements of the French language and in accordance with the rules of French morphology. I found only two words borrowed from English: covid19 and cluster (in the sense of >epidemic cluster $<$ ).

\subsection{The lexical creations of ordinary people}

The current health crisis involves the whole population in a way never seen before. The implications are great, and include being prohibited to leave home without a »permission slip«, having to wear a mask (which has generated a cultural upheaval), and lining up outside stores for a lengthy amount of time. In this unknown context, the best way to overcome the difficulties is to be inventive, notably on the lexical level, and for some, by way of social media.

So lexical creativity, the »watermark « just beneath the surface of many speakers, has been amplified during the health crisis, particularly during the first confinement period. An initiative taken by the newspaper Le Monde enabled the collection of new words describing the daily lives of readers and internet users during the initial confinement, as illustrated below.

\section{Example 21}

The calender [and] the clock seem to no longer make sense, while the meaning of words [...] is shifting as our live enters into confinement (»s'enconfine «). On Monday April 27, the readers of Le Monde listed, on its forum »Our Confined Lives «, the new words that described their daily lives. Lined up, these words describe idleness and anxiety, but also moments of winding down during this most unusual period. (Le Monde, April 27, 2020; our translation)

The creations are plentiful. Here are a few verbs: s'enconfiner (see above); covidéprimer (covid + >to get depressed $<$ ); se télédéconnecter ( >television $<+>$ disconnect oneself $<$ ); poubelliser, casseroliser, and vuvuzéliser (three verbs derived from $>$ trash cans $<$, >pots and pans $<$, and >noise makers $<$, used to accompany applause of health workers from one's balcony). Most of the nouns (in this corpus) are constructed on the portmanteau model, wherein two words, which may or may not be

\footnotetext{
${ }^{26}$ As Alain Rey said in the editorial of the press kit presenting 2021's new words, »The Petit Robert 2021
} had to deal with and adapt to an exceptional situation.«. 


\section{@azkoraa · 28 avr. 2020}

Salut mes petits confinés !!! Alors, comment s'est passé votre \#Lundimanche ? 75 Moi c'était sympatoche, j'ai fait un \#apérue avec mes amis mais tout en respectant la \#distanciation \#sociale hein $\approx$ C'est l'heure de ma séance de mon \#coronasport pour entretenir mes \#coronabdos
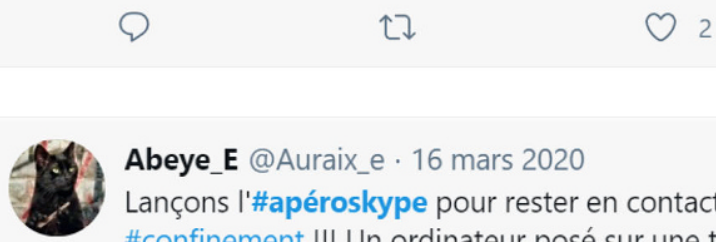

Abeye_E @Auraix_e.16 mars 2020

Lançons l'\#apéroskype pour rester en contact virtuel pendant le \#confinement !!! Un ordinateur posé sur une table de cuisine, une binouze, et des amis en réseaux.

Fig. 6 Tweets proposing hashtags with neologisms from the first confinement

truncated first, are combined into one word (as in the English word smog for smoke + fog) and here, in the French words apérue (aperitif + >street<) and skypapéro (Skype + aperitif). Some examples from our corpus are given below, in context.

- The week now consists of only one and the same day, which repeats in a loop, lundimanche ( $>$ Monday $<+>$ Sunday $<$ ).

- Others try to contribute and help as much as they can, in a boost of solidaritude ( $>$ solidarity $<+>$ solitude $<$ ).

- We stuff ourselves [...] and become victims of the dreadful immobésité (>immobile $<+>$ obesity $<$ )

- ... an upper deck, or even a window with a southern exposure, just perfect for a little session of homezage (>home $<+>$ suntanning $<$, from the French verb bronzage).

These neoglisms are quite whimsical; they will probably die out and never make it into a common French dictionary. Some have also circulated somewhat on social media like Twitter.

In the Figure 6 we find the hashtags \#Lundimanche, \#apérue, \#distanciation, \#social, \#coronasport (corona + sport), \#coronabdos (corona $+>$ abdominal muscle exercises<), \#apéroskype, and \#confinement.

\section{By way of a conclusion: Paving the way toward a contrastive discourse analysis}

The current health crisis has and still is affecting all areas of society and its people, who are plunged into the heart of the problem. There are many repercussions at the linguistic level. While we all see a health event here, there also exists a linguistic event in its wake, with an exuberance of discourse and lexical creations and an 
impact on languages all over the world. ${ }^{27}$ It is clear that the discourse neologisms and new words studied here are characteristic of the French language and culture, and that there are different repercussions in other societies, languages, and cultures. The question raised, then, concerns the passage from one language and culture to another. Going beyond translation, I am beginning some analyses in line with the work by Patricia von Münchow, who studies »contrastive discourse analysis«. This type of analysis points out the convergence between French discourse analysis, textlinguistics, and contrastive or »transcultural« approaches:

Its object is the comparison of different discursive cultures, a notion that encompasses the discursive manifestations of social representations, circulating in a given community, about social objects on one hand and about the discourse to use for those objects on the other. In this approach, it is not different languages that are compared, as is traditionally done in contrastive linguistics, but the manifestations of one and the same discursive genre in at least two different communities (or what is assumed to be communities). This genre is to be described and then its regularities and variabilities are to be interpreted. (von Münchow, in press; our translation).

Comparing journalistic discourse of a given genre on the theme of health crisis would allow us to delineate the different approaches that languages and cultures have of the covid-19 event, at both the discursive and lexical levels.

Acknowledgements I would like to thank Vivian Waltz for her masterful translation of this article.

\section{References}

Benveniste, Emile (1958/1966): De la subjectivité dans le langage. In: Benveniste, Emile: Problèmes de linguistique générale, tome 1. Paris: Gallimard, pp. 258-266. English version: Problems in general linguistics (1971). Miami: University of Miami Press.

Courtine, Jean-Jacques (1981): Quelques problèmes théoriques et méthodologiques en analyse du discours. In: Langages 62, pp. 9-128.

Détrie, Catherine/Siblot, Paul/Vérine, Bertrand (Eds.) (2001): Termes et concepts pour l'analyse du discours. Paris: Champion.

Le Petit Robert de la langue française (2020).

Londei, Danielle/Moirand, Sophie/Reboul-Touré, Sandrine/Reggiani, Licia (Eds.) (2013): Dire l'événement : langage, mémoire, société. Paris: Presses Sorbonne Nouvelle. URL: https://books.openedition.org/ psn/2935 (03.03.2021).

Marcellesi, Jean-Baptiste (1976): Analyse de discours à entrée lexicale (Application à un corpus de 19241925). In: Langages 41, Paris: Larousse, pp. 79-124.

Moirand, Sophie (2007): Discours, mémoires et contextes: à propos du fonctionnement de l'allusion dans la presse. In: Corela, HS-6. URL: http://journals.openedition.org/corela/1567 (03.03.2021).

\footnotetext{
27 »Coronavirus, une conversation mondiale: comment le Covid a-t-il modifié le langage ?« (〉Coronavirus, a worldwide conversation: How did Covid modify the language?<), January 29, 2021, https:// www.franceculture.fr/emissions/le-temps-du-debat/coronavirus-une-conversation-mondiale-commentle-covid-a-t-il-modifie-le-langage [retrieved March 3, 2021]. See also »Social change and linguistic change: the language of Covid-19«, https://public.oed.com/blog/the-language-of-covid-19/ [retrieved March 3, 2021] and »Words of the Year 2020«, https://languages.oup.com/word-of-the-year/2020/ [retrieved March 3, 2021].
} 
Moirand, Sophie/Reboul-Touré, Sandrine (2015): Nommer les événements à l'épreuve des mots et de la construction du discours. In: Langue française 188, pp. 105-120. URL: https://www.cairn.info/revuelangue-francaise-2015-4-page-105.htm (03.03.2021).

Moirand Sophie/Reboul-Touré, Sandrine/Pordeus, Michelle (2016): Popular science at the crossroads of new linguistic spheres. In: Bakhtiniana. Revista de Estudos do Discurso 11 (2). URL: http://www. scielo.br/j/bak/a/Qy69fwvJjCPvMnKQ8CnkNks/?lang=en French version: La vulgarisation scientifique au croisement de nouvelles sphères d'activité langagière. In: Bakhtiniana. Revista de Estudos do Discurso 11 (2), pp. 145-169. URL: https://revistas.pucsp.br/index.php/bakhtiniana/article/view/ 23847/19244 (03.03.2021).

Morin, Edgar (1976): Pour une crisologie. In: Communications 25, pp. 149-163. English version: For a crisiology, translated by Thierry C. Pauchant (1993). In: Industrial \& Environmental Crisis Quarterly 7 (1), pp. 5-21. URL: https://www.jstor.org/stable/26162559 (03.03.2021).

Morin, Edgar (2020): Sur la crise. Pour une crisologie [2016] suivi de Où va le monde [2017]. Paris: Flammarion.

Münchow, Patricia von (forthcoming): L'analyse du discours contrastive, un voyage au cœur du discours. In: Sheila Viera de Camargo Grillo/Sandrine Reboul-Touré/Maria Glushkova (Eds.): Analyse du discours et comparaison : enjeux théoriques et méthodologiques. Bern: Peter Lang.

Née, Émilie/Veniard, Marie (2012): Analyse du Discours à Entrée Lexicale (A.D.E.L.): le renouveau par la sémantique? In: Langage \& Société 140, pp. 15-28.

Petiot, Geneviève/Reboul-Touré, Sandrine (2009): Peut-on définir le >mot< ? In: Le français moderne 1 - La problématique du mot, $77^{\mathrm{e}}$ année, pp. 5-21. URL: https://fr.calameo.com/read/ 0009039478c34ae88dcd9?authid=CLse67TAtK1U (03.03.2021).

Quéré, Louis (2013): Les formes de l'événement. In: Elio Ballardini/Roberta Pederzoli/Sandrine ReboulTouré/Geneviève Tréguer-Felten (Eds.): Les facettes de l'événement: des formes aux signes, MediAzioni 15. URL: http://mediazioni.sitlec.unibo.it (03.03.2021).

Reboul-Touré, Sandrine (2016): L'évolution du mot bien-être dans la presse française: pour une lexicologie scalaire. In: Roberta Pederzoli/Licia Reggiani/Laura Santone (Eds.): Médias et bien-être: discours et représentations. Bologne: Bononia University Press, pp. 93-108.

Reboul-Touré, Sandrine (2020): La biodiversité: un mot-témoin pour l'analyse du discours. In: Les Carnets du Cediscor 15 - La biodiversité en discours: communication, transmission, traduction. Paris: Presses Sorbonne nouvelle, pp. 16-32. URL: https://journals.openedition.org/cediscor/2662 (03.03.2021)

Sablayrolles, Jean-François (2019): Comprendre la néologie. Conceptions, analyses, emplois. Limoges: Editions Lambert-Lucas.

Siblot, Paul (1990): Une linguistique qui n'a plus peur du réel. In: Cahiers de praxématique 15. URL: https://journals.openedition.org/praxematique/3154 (03.03.2021).

Siblot, Paul (1997): Nomination et production de sens: le praxème. In: Langages 127, pp. 38-55.

Thiéry-Riboulot, Véronica (2020): Une étude de sémantique historique du mot confinement. In: Mots. Les langages du politique 124. URL: http://journals.openedition.org/mots/27382 (03.03.2021).

Veniard, Marie (2013): Du profil lexico-discursif du mot »crise« à la construction du sens social d'un événement. In: Danielle Londei/Sophie Moirand/Sandrine Reboul-Touré/Licia Reggiani (Eds.): Dire l'événement: langage, mémoire, société. Paris: Presses Sorbonne Nouvelle, pp. 221-232. 